Folia Cardiologica 2017

\title{
Uporczywe, groźne komorowe zaburzenia rytmu jako późny objaw reperfuzji u chorego z zawałem serca leczonego angioplastyką tętnic wieńcowych*
}

\author{
Persistent, life-threatening ventricular arrhythmias as a late manifestation \\ of reperfusion in a patient with myocardial infarction treated \\ with coronary angioplasty
}

\author{
Michał Bączek ${ }^{1,2}$, Marian Sierant ${ }^{3}$, Iwona Gorczyca-Michta ${ }^{1}$, \\ Kamilla Wesołowska ${ }^{1}$, Beata Wożakowska-Kapłon ${ }^{1,2}$ \\ ${ }^{1}$ K Klinika Kardiologii i Elektroterapii Świętokrzyskiego Centrum Kardiologii w Kielcach \\ ${ }^{2}$ Wydział Lekarski i Nauk o Zdrowiu Uniwersytetu Jana Kochanowskiego w Kielcach \\ ${ }^{3}$ Oddział Kardiologii Szpitala Specjalistycznego w Końskich
}

\section{Streszczenie}

Przedstawiono opis przypadku 66-letniego chorego z zawałem serca z uniesieniem odcinka ST, z wielonaczyniową chorobą wieńcową, nawracającymi częstoskurczami komorowymi, po rewaskularyzacji przezskórnej tętnic wieńcowych, przekazanego ze szpitala rejonowego w celu rozważenia wskazań do implantacji kardiowertera-defibrylatora. Na podstawie prezentowanego przypadku autorzy zwracają uwagę na trudności w podejmowaniu decyzji dotyczących postępowania u chorych z uporczywymi arytmiami komorowymi w przebiegu ostrych zespołów wieńcowych.

Słowa kluczowe: komorowe zaburzenia rytmu, częstoskurcz komorowy, migotanie komór, powikłanie angioplastyki

Folia Cardiologica 2017; 12, 1: 124-127

\section{Wstęp}

Zawał serca z uniesieniem odcinka ST (STEMI, myocardial infarction with ST-segment elevation) wywołuje zaburzenia metaboliczne i elektrofizjologiczne mięśnia sercowego, które mogą prowadzić do komorowych zaburzeń rytmu serca (VA, ventricular arrhythmias). U 6\% pacjentów ze STEMI w pierwszych $48 \mathrm{~h}$ od początku objawów występuje utrwalony częstoskurcz komorowy (sVT, sustained ventricular tachycardia), który wywołuje niestabilność hemodynamiczną lub może prowadzić do nagłego zatrzymania krążenia w mechanizmie migotania komór (VF, ventricular fibrillation). Większość przypadków tych zagrażających życiu zaburzeń rytmu pojawia się jeszcze przed zabiegiem rewaskularyzacji lub w jego trakcie. Wśród czynników ryzyka wystąpienia sVT/VF wymienia się starszy wiek, wyższy stopnień w klasyfikacji Killipa-Kimballa, rozleglejsze zmiany odcinka ST w elektrokardiogramie (EKG) oraz gorszy przepływ przez naczynia wieńcowe w skali TIMI (Thrombolysis In Myocardial Infarction) przed rewaskularyzacją. Wystąpienie sVT/VF wiąże się z pogorszeniem rokowania, zwiększając śmiertelność krótko- i długoterminową w porównaniu z pacjentami bez incydentu SVT/VF [1]. 


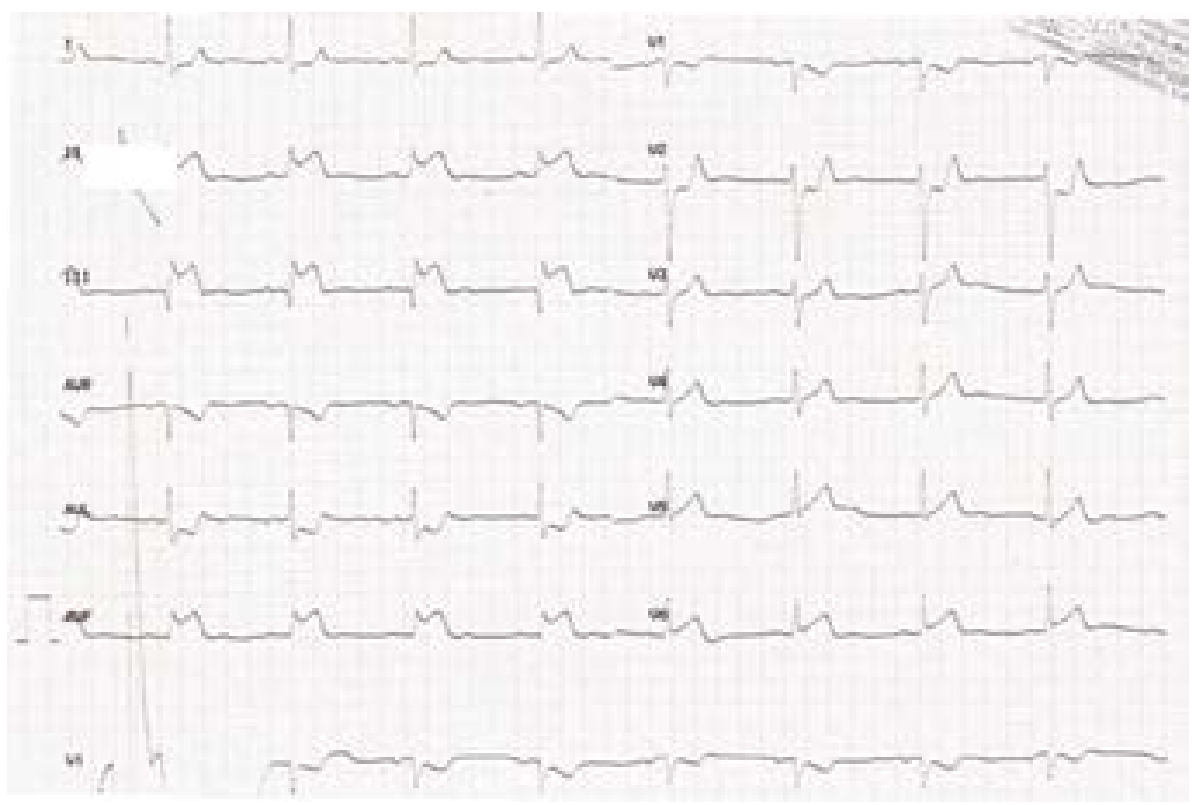

Rycina 1. Zapis elektrokardiograficzny przy przyjęciu do szpitala - uniesienia odcinka ST-T w odprowadzeniach II, III i aVF oraz obniżenie odcinka ST-T w odprowadzeniach I, aVL i V1-V2

\section{Opis przypadku}

Chory w wieku 66 lat, z wywiadem nadciśnienia tętniczego i hipercholesterolemią, obciążony wywiadem rodzinnym, został przyjęty na oddział kardiologii szpitala rejonowego z powodu wystąpienia ostrego zespołu wieńcowego. W badaniu EKG rejestrowano uniesienie odcinka ST w odprowadzeniach II, III i aVF oraz obniżenie w odprowadzeniach I, aVL i V1-V2 (ryc. 1). W badaniu echokardiograficznym obserwowano odcinkowe zaburzenia kurczliwości pod postacią akinezy ściany dolnej oraz dolno-bocznej z globalną frakcją wyrzutową lewej komory (LVEF, left ventricular ejection fraction) około $50 \%$. W badaniach laboratoryjnych stwierdzono znamienne podwyższenie stężenia troponiny $T$ oznaczonej w teście wysokoczułym - 0,024 ng/ml (norma 0-0,014). U chorego rozpoznano STEMI ściany dolnej.

Wykonano koronarografię, podczas której stwierdzono krytyczne (90\%) zwężenie proksymalnego odcinka gałęzi przedniej zstępującej (LAD, left anterior descending) lewej tętnicy wieńcowej oraz zamkniętą prawą tętnicę wieńcową (RCA, right coronary artety) ze świeżą skrzepliną. Odessano skrzeplinę ze światła RCA i jednoczasowo wykonano przezskórną angioplastykę wieńcową (PTCA, percutaneous transluminal coronary angioplasty) RCA z wszczepieniem stentu uwalniającego lek (DES, drug-eluting stent), uzyskując końcowy przepływ w naczyniu TIMI równy 3. W 2. dobie hospitalizacji występowały nawracające epizody sVT oporne na leczenie farmakologiczne ( $\beta$-adrenolityki, amiodaron, lidokainę) przechodzące W VF wymagające defibrylacji elektrycznej. Wykonano kontrolną koronaro- grafię, w której uwidoczniono dobry wczesny efekt PTCA RCA. Jednocześnie podjęto próbę rewaskularyzacji LAD. W trakcie zabiegu wystąpiły kolejne epizody sVT (ryc. 2), a podczas implantacji stentu w proksymalnym odcinku LAD doszło do zatrzymania krążenia w mechanizmie VF ze skuteczną defibrylacją. Choremu implantowano dwa stenty typu DES w proksymalnym odcinku LAD. Po zabiegu w ciągu 48 h występowały nawracające epizody VT; u chorego założono elektrodę do stymulacji czasowej w celu stymulacji serca o typie overdriving. W trakcie wprowadzania elektrody do prawej komory ponownie doszło do zatrzymania krążenia w mechanizmie VF. W 5. dobie hospitalizacji pacjenta skierowano do ośrodka o wyższym stopniu referencyjności, by rozważono u niego implantację kardiowertera-defibrylatora (ICD, implantable cardioverter-defibrillator). W klinice kardiologii usunięto elektrodę do czasowej stymulacji. W 48-godzinnym monitorowaniu EKG metodą Holtera oraz elektrokardiograficznej próbie wysiłkowej, wykonanej w 12. dobie po zawale serca, nie obserwowano groźnych VA. W wyniku konsultacji w ramach Kardiogrupy pacjenta zakwalifikowano do leczenia zachowawczego. Chory pozostaje w 3-miesięcznej obserwacji, bez nawrotów arytmii.

\section{Omówienie}

Komorowe zaburzenia rytmu są groźnym powikłaniem związanym z rewaskularyzacją u pacjentów ze STEMI. Wystąpienie VA może się wiązać zarówno z niedokrwieniem komórek mięśnia sercowego, jak i z przywróceniem przepływu przez 


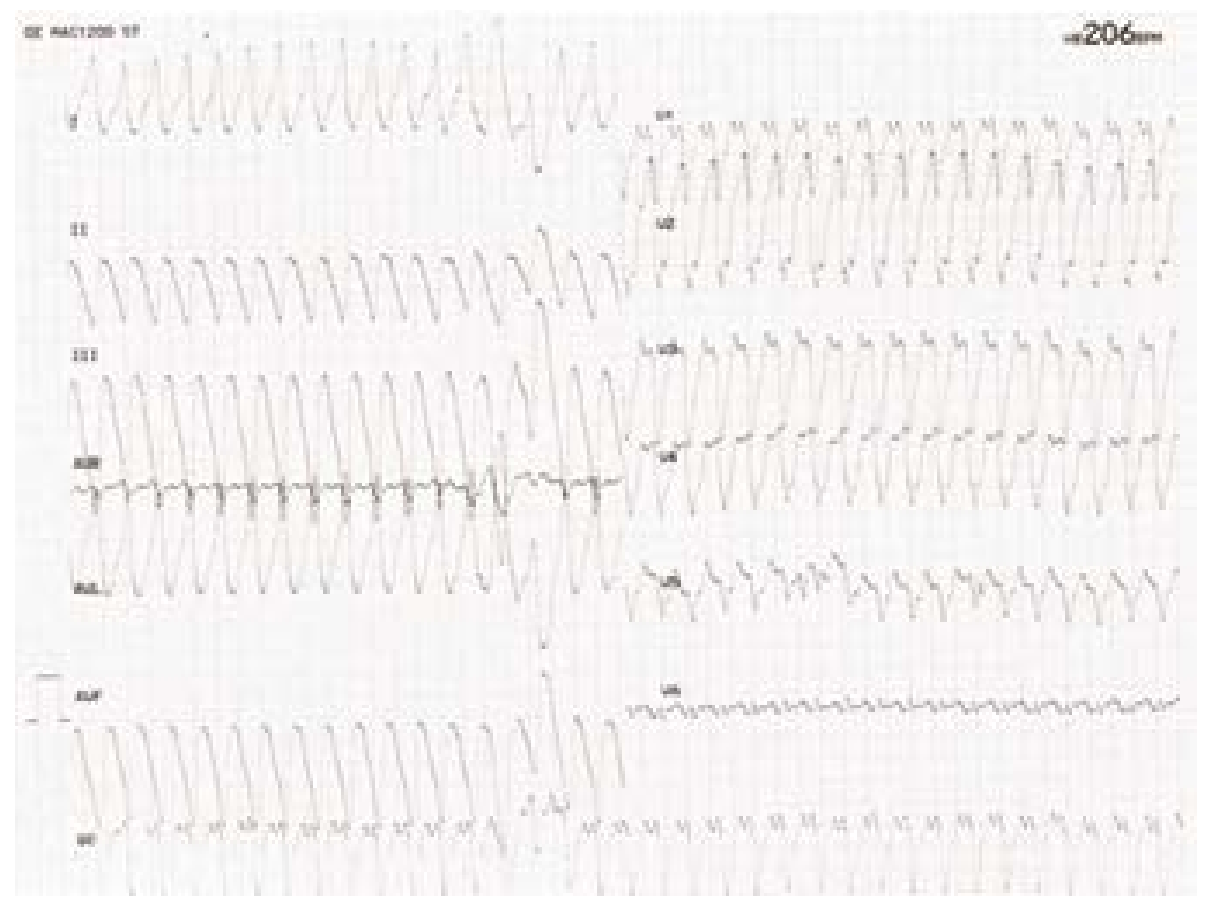

Rycina 2. Utrwalony częstoskurcz komorowy podczas przezskórnej angioplastyki wieńcowej gałęzi przedniej zstępującej

uprzednio zamkniętą tętnicę wieńcową. Niedokrwienne tło groźnych zaburzeń rytmu stanowi nagłe zamknięcie światła nasierdziowej tętnicy wieńcowej lub powikłania związane z zabiegiem rewaskularyzacji (np. przemieszczenie skrzepliny wzdłuż naczynia, uszkodzenie blaszki miażdżycowej końcówką cewnika) [2]. Zaburzenia reperfuzyjne powstają po przywróceniu przepływu w naczyniu dozawałowym. Reperfuzja może powodować śmierć kardiomiocytów oraz hemodynamiczną i elektrofizjologiczną niestabilność [3]. Trudnym zadaniem staje się stwierdzenie, czy zaburzeń rytmu serca powstały w wyniku trwającego niedokrwienia mięśnia sercowego czy uzyskania reperfuzji, gdyż u pacjentów ze STEMI oba procesy toczą się równocześnie.

W prezentowanym przypadku zasadniczą przyczyną VT/VF wydają się zmiany elektrofizjologiczne związane z reperfuzją obszaru unaczynionego przez RCA. Istnieje zwiększone ryzyko wystąpienia groźnych zaburzeń rytmu, gdy tętnicą dozawałową jest RCA [4], jednak mechanizm tego zjawiska nie jest w pełni poznany. Uważa się, że nagłe przywrócenie przepływu w obrębie RCA zwiększa napięcie nerwu błędnego poprzez odruch Bezold-Jarisha, co skutkuje kompensacyjnym pobudzeniem układu współczulnego
[5]. Uporczywość i groźny charakter tych zaburzeń, mimo zastosowania optymalnego postępowania profilaktycznego i terapeutycznego, skłoniły kardiologów z ośrodka rejonowego do zastosowania leczenia za pomocą elektroterapii pod postacią stymulacji typu overdriving i przekazania chorego do ośrodka o wyższym stopniu referencyjności.

Należy także podkreślić, że ICD we wczesnym okresie pozawałowym, według obowiązujących zaleceń, należy implantować u chorego z udokumentowanym VF lub nietolerowanym hemodynamicznie VT bez odwracalnej przyczyny [6]. U opisanego pacjenta odstąpiono od implantacji ICD ze względu na uzyskanie stabilizacji elektrycznej mięśnia sercowego oraz ustąpienie przyczyny VT/VF, którą były poreperfuzyjne zaburzenia rytmu serca.

Pacjenci z ostrym zespołem wieńcowym i VA to niejednorodna grupa chorych, w której decyzje, zarówno dotyczące rewaskularyzacji, jak i wszczepienia ICD, wymagają wnikliwego rozpatrzenia i indywidualizacji postępowania.

\section{Konflikt interesów}

Autorzy nie zgłaszają konfliktu interesów. 


\section{Abstract}

We present a case of a 66-year-old patient with myocardial infarction with ST-segment elevation, multivessel coronary artery disease and recurrent ventricular tachycardia after percutaneous coronary angioplasty. Patient was transferred to our Clinic to consider implantable cardioverter-defibrillator implantation. On the basis of the presented case, authors point out difficulties in making decisions concerning management of patients with persistent ventricular arrhythmias complicating acute coronary syndrome.

Key words: ventricular arrhythmias; ventricular tachycardia; ventricular fibrillation; coronary artery complication

Folia Cardiologica 2017; 12, 1: 124-127

\section{Piśmiennictwo}

1. Windecker $\mathrm{S}$, Kolh $\mathrm{P}$, Alfonso $\mathrm{F}$, et al. Authors/Task Force members. 2014 ESC/EACTS Guidelines on myocardial revascularization: the Task Force on Myocardial Revascularization of the European Society of Cardiology (ESC) and the European Association for Cardio-Thoracic Surgery (EACTS)Developed with the special contribution of the European Association of Percutaneous Cardiovascular Interventions (EAPCI). Eur Heart J. 2014; 35(37): 2541-2619, doi: 10.1093/eurheartj/ /ehu278, indexed in Pubmed: 25173339.

2. Priori SG, Blomström-Lundqvist C, Mazzanti A, et al. 2015 ESC Guidelines for the management of patients with ventricular arrhythmias and the prevention of sudden cardiac death: The Task Force for the Management of Patients with Ventricular Arrhythmias and the Prevention of Sudden Cardiac Death of the European Society of Cardiology (ESC).
Endorsed by: Association for European Paediatric and Congenital Cardiology (AEPC). Eur Heart J. 2015; 36(41): 2793-2867, doi: 10.1093/ /eurheartj/ehv316, indexed in Pubmed: 26320108.

3. Bougouin W, Marijon E, Puymirat E, et al. FAST-MI Registry Investigators. Incidence of sudden cardiac death after ventricular fibrillation complicating acute myocardial infarction: a 5-year cause-of-death analysis of the FAST-MI 2005 registry. Eur Heart J. 2014; 35(2): 116-122, doi: 10.1093/eurheartj/eht453, indexed in Pubmed: 24258072.

4. Kusumoto FM, Calkins H, Boehmer J, et al. HRS/ACC/AHA expert consensus statement on the use of implantable cardioverter-defibrillator therapy in patients who are not included or not well represented in clinical trials. Circulation. 2014; 130(1): 94-125, doi: 10.1161/ /CIR.0000000000000056, indexed in Pubmed: 24815500. 